FACTA UNIVERSITATIS

Series: Law and Politics Vol. 16, $\mathrm{N}^{\circ} 1,2018$, pp. 69-79

https://doi.org/10.22190/FULP1801069L

Review Paper

\title{
COMPENSATION OF CIVIL PROCEDURE COSTS IN MASS TORT LITIGATION
}

\author{
UDC 347.921.6/.922
}

\section{Ana Lukić Vidojković}

Basic Court in Niš, Republic of Serbia

\begin{abstract}
This paper examines the legal consequences of mass tort litigation where the amount of damages is multiple times lower than the litigation cost. In the context of current judicial practice, the author observes this phenomenon from the aspect of prohibition of abuse of rights, and offers proposals for improving the existing regulation in order to effectively prevent the abuse of rights.
\end{abstract}

Key words: mass tort lawsuits, litigation costs, abuse of rights.

\section{INTRODUCTION}

Acting on behalf of the plaintiff N. N., a lawyer filed a complaint with the Basic (Municipal) Court in Niš against the National Employment Service, the defendant, seeking damages for unemployment compensation which was not paid in full and litigation costs. The Basic Court ruled that the defendant shall pay the plaintiff the amount of 890,74 RSD (dinars) as damages, and the amount of 42,800.00 dinar as litigation costs. ${ }^{1}$ In another case adjudicated by the same Court, a lawyer filed a complaint on behalf of the communal services company "Objedinjena naplata" (administering the payment of communal utility bills) against the defendant N. N., seeking payment of debt for provided communal services and litigation costs. The Court ruled that the defendant shall pay the debt in the amount of 2,767.00 RSD as well as litigation costs in the amount of $24,200.00 \mathrm{RSD}^{2}$ In a third case, a lawyer filed a complaint on behalf of the public communal services company "Parking servis" against the defendant N. N, seeking payment of debt and litigation costs. The Court ruled that the defendant shall pay to the plaintiff the debt in the amount of 6,724.00 RDS the litigation costs in the amount of $34,800.00 \mathrm{RSD}^{3}$

Received October $24^{\text {th }}, 2017 /$ Accepted September $18^{\text {th }}, 2018$

Corresponding author: Ana Lukić Vidojković, Judge, Basic Court in Niš, Vožda Karađorđa 23, 18000 Niš, Republic of Serbia

E-mail: ana.lukic@ni.os.sud.rs

${ }^{1}$ Judgment of the Basic Court in Niš P 6750/15 dated 12/09/2017.

${ }^{2}$ Judgment of the Basic Court in Niš P 2706/14 dated 05/03/2015.

${ }^{3}$ Judgment of the Basic Court in Niš P 14313/15 dated 13/09/2016. 
These examples are only some of the many types of mass tort lawsuits which are being tied in Serbian courts. Irrespective of whether the complaint is filed by a natural or a legal person, the main characteristic of such lawsuits is the plaintiff vests the power of attorney in their lawyers, that the litigation costs are necessarily awarded in a vast majority of cases, considering that the defendants are solvent legal persons ${ }^{4}$, or due to the fact that the plaintiff is a solvent legal person ${ }^{5}$. The judicial practice shows that the complaints are justified in almost all of these cases; as a result, the defendant is ordered to compensate the plaintiff for the litigation costs. The amount of compensation for litigation costs substantially exceeds the value of the legal claim. ${ }^{6}$

Mass tort lawsuits are a controversial phenomenon which attracted media attention and provoked various public responses. One of the questions posed in this respect is whether such cases may be said to entail the abuse of rights. The paper is dedicated to this issue. ${ }^{7}$ Relying on the analysis of the existing judicial practice, the goal of the paper is to consider possible solutions which would prevent any kind of abuse in compliance with the principle of prohibition of abuse of rights. For the purpose of providing a comprehensive review of the problem, the first part of the paper presents key features of the mass tort litigation phenomenon; the second part of the paper focuses on the litigation costs reimbursement regime, and the third (central) part of the paper considers whether there the parties' rights have been abused in these lawsuits and provides possible solutions to prevent the occurrence of abuse.

\section{CONCEPT AND CHARACTERISTICS OF MASS TORT LITIGATION}

The emergence of the so-called mass harm situations, involving the violation of rights of a large number of persons caused by the unlawful conduct of the same legal person, has resulted in a divergence from the concept of litigation as an instrument for protection of an individual plaintiff against an individual defendant, and introducing legal institutes that are more efficient in resolving mass (collective) disputes. In this respect, the legislation of the United States of America recognizes the institute of class action; ${ }^{8}$ the United Kingdom has the institute of representative proceedings, ${ }^{9}$ Austria, Germany and Greece have instituted the test litigation

\footnotetext{
${ }^{4}$ The National Employment Agency, Pension and Disability Insurance Fund, Tobacco Industry Niš, the City of Niš, Preschool institution „Pčelica“, Niš.

${ }^{5}$ Public community service (PCS) “Objedinjena naplata“ Niš, and PCS „Parking servis “ Niš (respectively).

${ }^{6}$ In the lawsuits against the National Employment Service, the plaintiffs were awarded up to 60,000 RSD each on the average, but more than two thirds of this amount relates to compensation for litigation procedure costs: judicial fees and lawyer fees. See:http://www.paragraf.rs/dnevne-vesti/300916/300916-vest6.html (accessed 12/ 10/2017).

${ }^{7}$ In mass tort litigation, there is also a problem of uneven application of law, which puts legal subjects in an unequal position regarding the exercise of their rights. These lawsuits also generate a heavy caseload for courts, which has a negative impact on efficiency. Due to the page limit, these issues are not the subject matter of analysis in this paper.

${ }^{8}$ See: Rule 23 of Federal Rules of Civil Procedure, USA; available at www.federalrulesofcivilprocedure.org (accessed 12/10/2017). "Class action lawsuit is a procedural instrument which enables the plaintiff to initiate a civil procedure for the infringement of his own rights, not only on his own behalf but alsoon behalf of other persons who find themselves in the same or similar legal situation, because their rights were violated in the same way by the same subject" (the definition taken from Janićijević, 2006: 111). See more on class action lawsuits in: Sherman, 2002.

${ }^{9}$ See more: E. Shreman, 2002: 422
} 
model $^{10}$ in Austria, Germany and Greece, whereas Slovenia recognizes the sample model. ${ }^{11}$ For the purpose of harmonizing the national legislations of EU member states, enabling unhindered access to justice and equal legal protection, in June 2013, the European Commission adopted the Recommendation on common principles for injunctive and compensatory collective redress mechanisms in the Member States concerning violations of rights granted under Union, was adopted by the European Commission in June $2013^{12}$.

The current Civil Procedure Act of the Republic of Serbia (2014) ${ }^{13}$ does not recognize any institute similar to the ones listed. In the Civil Procedure Act of 2011, Chapter 36 regulates "The procedure for protection of citizens' collective rights and interests" 14 , but these provisions were found to be unconstitutional.

The concept of "mass tort" originated in the judicial practice and it signifies the existence of a significant number of lawsuits which have the same factual and legal basis; yet, in a number of such cases, the plaintiffs are natural persons while the defendant is the same legal person (most frequently the city or an organization vested with public authorities ${ }^{15}$ or a public company), whereas in other cases the plaintiff is a public company and the defendants are users of its services. ${ }^{16}$

In recent years, the number of such lawsuits is steadily rising. ${ }^{17}$ In some courts, these cases prevail in comparison to all other lawsuits, which is the situation in the Basic Court in Niš ${ }^{18}$. Almost all "mass torts" are proceedings in cases on small value disputes. ${ }^{19}$ Civil

\footnotetext{
${ }^{10}$ It is a "procedure where one plaintiff files an individual lawsuit for protection of his rights, where he files a motion to determine the existance of the violation, as well as to determine that all persons in same circumstances have the right to file a claim for compensation of the damage incurred. If the plaintiff is successful in the procedure, all other persons may initiate subsequent proceedings, where the subject matter of decision will be only the claim of these persons for damage compensation, without examining whether the violation had occurred in the first place". The definition was taken from: T. Zoroska-Kamilovska, T. Shterjova, 2014: 49.

${ }^{11}$ See: Art. 279b of the Civil Procedure Act of the Republic of Slovenia 26/1999-45/2000. More on the procedure: Betetto, 2011: 231-241.

${ }^{12}$ Commission Recommendation of 11 June 2013 on common principles for injunctive and compensatory collective redress mechanisms in the Member States concerning violations of rights granted under Union Law (2013/396/EU), Official Journal L 201/60, 26/7/2013, abbreviated as "Colective Redress Recommendation", [Electronic version]. Retrieved 4 April 2014 from http://eur-lex.europa.eu/legal-content/EN/TXT/PDF/?uri=uriserv: OJ.L.2013.201.01. 0060.01.ENG. See: N. Petrušić, 2014: 303-324.

${ }^{13}$ The Civil Procedure Act (hereinafter: CPA), Official Gazette of RS, no. 72/2011, 49/2013-decision of the Constitutional Court, 74/2013- decision of the Constitutional Court, 55/2014.

${ }^{14}$ Civil Procedure Act (CPA), Official Gazette of RS, no. 72/2011, and the decision of the Constitutional Court IUZ 51/2012 from 23/05/2013 published in the Official Gazette of RS, no. 49/2013. More on this procedure: N. Petrušić, D. Simonović, 2012: 890-903.

${ }^{15}$ According to data from the Communication of the National Employment Service, there were over 40,000 lawsuits filed against this organization for damages due to allegedly incomplete payments for unemployment, with over 10,000 court decisions in favour of the plaintiffs. See: http://www.paragraf.rs/dnevne-vesti/300916/300916-vest6.html (accessed 12/10/2017).

${ }^{16}$ The statistical data from the electronic record of the Basic Court in Niš show that a total of 18,998 lawsuits were received in 2015, out of which 2,439 lawsuits were filed against the National Employment Service, 363 lawsuits were filed against the PCS"Parking servis" Niš, and 578 lawsuits were filed against PCS "Objedinjena naplata"Niš. In 2016, the total number of filed lawsuits was 12,872, out of which 1,502 were against the National Employment Service, 228 lawsuites were against PCE ,Parking servis “ Niš, 416 lawsuits were against PCS “Objedinjena naplata“ Niš, and 1,465 lawsuits were filed against the Preschool institution „P čelica“ Niš and the City of Niš.

${ }^{17}$ Out of 33,700 unresolved civil cases in the First Basic Court in Belgrade and 4,500 unresolved cases in the Second Basic Court in Belgrade, one third of cases relates to small claim disutes. Almost all lawsuits involving public preschool institutions and enterprises "Infostan", "Vodovod" and "Parking servis" entail small vlaue claims. See: http://www.pravniportal.com/trajanje-sporova-male-vrednosti/ (accessed: 12/10/2017).

${ }^{18}$ See footnote 16 .
} 
procedure costs, which are claimed and often accepted in such cases, are often much higher than the original claim which is the subject matter of the lawsuit ${ }^{20}$.

\section{Civil PRocedure Costs}

Civil procedure $\operatorname{costs}^{21}$ are the expenses made during the procedure or in respect thereof, and they include fees for lawyers' services and the work of other persons whose right to remuneration is recognized by law (Article $150 \mathrm{CPA}$ ). The amount of lawyers' fees is regulated by the Tariff on Lawyers' Fees and Expenses ${ }^{22}$, while the fees and expenses for expert witnesses' work is regulated by the Rulebook on Expenses in Court Proceedings. ${ }^{23}$ Other expenses incurred in court proceedings may include expenses for court fees (taxes) in accordance with the Act on Court Fees, ${ }^{24}$ and expenses for presentation of evidence, such as: accepted expenses for witnesses (Article 258 CPA; Articles 5-13 Rulebook), parties (Article 283 CPA; Articles 5-13 Rulebook), and judicial examinations outside the court building ${ }^{25}$.

All expenses incurred during the civil procedure are initially charged to the party (Article 151 CPA). The final decision on the payment of litigation procedure costs is made by the court, at the request of a party. There are two principles guiding the decision on who will bear the final costs of the procedure: the principle of risk ${ }^{26}$ and the principle of liability (fault) ${ }^{27}$.

\footnotetext{
${ }^{19}$ Lawsuits on small value claims pertain to lawsuits where monetary claims (receivables) that do not exceed the RSD equivalent of EUR 3,000 at the middle exchange rate of the National Bank of Serbia on the day of payment, lawsuits where the subject matter of the claim does not pertain to monetary claims but the plaintiff has stated in the complaint that he agrees to receive the said amount instead of performance of a particular request; and disputes where the plaintiff determines the value of the subject matter of dispute to a specific amount, and it is not a monetary claim. The legislator has envisaged a special litigation procedure for small claim disputes. This procedure is regulated in Chapter 33 of the Civil Procedure Act (CPA), and it is significantly different from the general civil procedure; the special rules provided therein aim to enable more efficient and economical resolution of small claim disputes, which are presumably of a relatively minor importance to the parties. See more on this procedure: N. Petrušić, D. Simonović, 2012: 862-883; S. Zarić, 2005: 253-278; N. Bodiroga, 2015: 653-670.

${ }^{20}$ See the Introduction to this paper.

${ }^{21}$ On civil procedure costs see: B. Poznić, V. Rakić-Vodinelić, 2010: 433; G. Stanković, 1998: 285; S. Triva, M. Dika, 2004: 462; I. Grbin, 1990: 86.

${ }^{22}$ Tariff on Lawyers' Fees and Expenses, Official Gazette RS, no. 121/12 (hereinafter: Lawyers' Tariff). The Lawyers' Tariff envisages lawyers fees in lawsuits where the value of the subject matter of dispute is up to 450,000.00 RSD; thus, the lawyer is entitled to receive the amount of 6,000.00 RSD for drafting the compaint and all subsequent submissions (pleadings); the amount of 7,500.00 RSD for legal representation in a hearing; the amount of 4,500.00 dinar for appearing in a hearing which was not held due to the other party's failure to appear; and the amount of 12,000.00 RSD for drafting an appeal.

${ }^{23}$ Rulebook on Expenses in Court Proceedings, Official Gazette of RS, no. 6/16 and 62/16, (hereinafter: Rulebook).

${ }^{24}$ Act on Court Fees, Official Gazette of RS, no. 28/94, 53/97, 16/97, 34/01-the second law, 9/02, 29/04, 116/08the second law, 31/09, 101/11, 93/14 and 106/15. The amount of court fee (tax) for filing a complaint and delivering a final judgment in cases where the value of the subject matter of dispute does not exceed 10,000.00 RSD is 1,900.00 RSD; for values between 10,000 and 100,000 RSD, the legislator envisages the payment of 4\% of the dispute subject matter value increased by 1,900.00 RSD; for values over 100,000 up to 500,000 RSD is $2 \%$ of the dispute subject matter value increased by 9,800.00 RSD. The fee for delivering the final judgment based on admission and judicial settlement is half the amount of the envisaged tax fee for filing a complaint.

${ }^{25}$ Decision on cost compensation for payment of flat-rate fees to judges and employees of the Basic Court in Niš, as well as compensation for the use of institution vehicles, Cy I-1 6/16 dated 18/04/2016.

${ }^{26}$ On risk principle, see more in M. Marković, 1982:147.

${ }^{27}$ See more on the principle of liability (fault) in: M. Marković, 1982: 149.
} 
The principle of liability (fault) implies that the costs shall be paid by the party which has contributed to incurring the costs by its actions, or that the costs have been incurred by the event that involved that party, regardless of the final outcome of the lawsuit (Article 155 CPA). The principle of risk implies that the losing party will compensate the opposing party for the costs incurred (Article 153, para. $1 \mathrm{CPA}$ ). The ratio of such a principle is reflected in the fact that the party which has won the lawsuit is the party which succeeded to prove the veracity of its allegations, to substantiate that the claim was well founded and that the civil procedure was justified, all of which fully justifies the incurred litigation costs as well. A party which lost the lawsuit was "wrong", the party's claim was ill-founded, and it is therefore obliged to compensate the cost and expenses to the opposing party.

Obviously, the court will not recognize all the requested costs and expenses to the winning party, but only those that were necessary for handling the lawsuit (Article 154 CPA). The law does not give detailed instructions to the court on what these costs are; thus, taking into account all the circumstance in each particular case, the court will determine the costs necessary for civil proceedings. It is customary to recognize the following costs as necessary: court tax fees, lawyers' fees for drafting the complaint and other submissions, as well as lawyer fees for appearance in hearings.

Comparing the amount of awarded litigation procedure costs with the small amounts of claims in mass tort lawsuits imposes the need to address and respond to several key questions: what are the necessary costs involved in mass tort litigation; has the the winning party in any way contributed to incurring such costs; and is there abuse of rights in mass tort lawsuits, and if so, which ones?

\section{IS THERE ABUSE OF RIGHTS IN MASS TORT LITIGATION?}

Abuse of rights occurs when a right holder uses his right contrary to the purpose it has been established for ${ }^{28}$. The Civil Procedure Act prescribes that the parties shall use their rights given by the Act conscientiously (in good faith), and that the Court shall prevent and punish any abuse of rights that the parties are entitled to in civil proceedings (Article 9 CPA). The action involving abuse of rights may be completely legitimate and proper in terms of its external nature, but it shall be deemed impermissible in terms of its effects and the objective the right holder is striving for. ${ }^{29}$ In light of the issue under observation, this would mean that the law entitles an individual to initiate civil action for the purpose of protecting his/her rights. By filing a complaint, the plaintiff initiates a litigation proceeding, which incurs certain costs; hence, the legislator recognizes the right of an individual to seek compensation for such costs which have been incurred in the course and for the purpose of exercising the right to legal protection. Therefore, the actions of filing a complaint and submitting a claim for compensation of costs are completely legitimate and correct, but can such actions sometimes constitute the abuse of rights?

The increasing number of mass tort lawsuits with high litigation procedure costs and small values of claims calls for examining the causes of such a phenomenon and responding to the following question: what is the actual motive governing the plaintiff's pursuit to protect his low-value claim in such an expensive procedure?

\footnotetext{
${ }^{28}$ See more on abuse of the right in: M. Marković, 1996; M. Popović, 1996: 3-10; G. Vukadinović, 1996: 1116; R. Kovačević-Kuštrimović, 1996: 17-30; V. V. Vodinelić, 1997.

${ }^{29}$ See: D. Stojanović, 1970: 92
} 
The Civil Procedure Act acknowledges the right of the winning party to seek compensation of costs from the losing party, in the amount which is not dependent on the value of the claim, the only condition being that the costs were necessary (Article 154 CPA); neither this Act nor any other regulations ${ }^{30}$ envisage that evidence shall be provided on the actual payment of these costs in the claimed amounts, nor is the fulfillment of this condition required in the judicial practice. ${ }^{31}$

Accordingly, the plaintiff does not incur any costs in the course of the proceeding; all the costs he has to pay, either to the court or to his attorney, will be paid by the opposing party upon the completion of the proceedings, either voluntarily or under force. Thus, it may be concluded that civil procedure is free of charge for the plaintiff, for which reason he actually enters the procedure; the final amount of costs is not a matter of his concern: for, he will only obtain the requested amount of his small value claim, whereas his lawyer will receive a much higher amount of the procedure costs.

On the basis of these circumstances, the fact that the final outcome of proceedings in mass tort lawsuits is largely predictable, as well as the fact that one lawyer often represents dozens and even hundreds of clients or files a lawsuit against a large number of persons on behalf of one plaintiff, it may be concluded that such proceedings are entered into only for the purpose of claiming the litigation procedure costs.

As the factual and legal grounds in mass tort litigation are almost identical, the lawyers acting on behalf of their clients commonly undertake the same legal activities: file complaints with almost identical content, submit motions with the same content, reiterate in hearings the same allegations contained in the complaints and submissions, and propose adducing the same evidence. The only difference is in written submissions, which include different personal data of the plaintiffs, claim amounts, and sometimes the specific period that the claim is requested for.

When a lawyer represents more than one client, the Lawyers' Tariff ${ }^{32}$ prescribes that his $^{\prime}$ original fee is additionally increased by $50 \%$ for every action undertaken on behalf of the second and every additional client. Thus, if a lawyer filed a lawsuit for multiple plaintiffs, he would be entitled to ask for a little more than $50 \%$ of the total procedure costs as compared to those which he would be entitled to seek if he filed individual lawsuits. Such an increase does not exist when a civil action is initiated against multiple defendants. To conclude, it is economically viable to run multiple proceedings, and multiple actions lead to the emergence of "mass tort lawsuits".

The aforementioned provision refers the abuse of right to legal protection and to the abuse of right to compensation of litigation costs.

The right to legal protection is abused by turning the civil procedure into a mechanism for the legitimate acquisition of gain. The primary goal of such mass tort litigation is not the protection of individual rights, but the collection of litigation costs. This type of abuse is exercised by some lawyers who "choose" not to file a single lawsuit on behalf of all their clients against the same defendant but, instead, they file separate lawsuits, sometimes even several lawsuits on behalf of a single client because it is more cost-effective from the standpoint of procedure costs. ${ }^{33}$ In this way, the right to compensation of procedure costs

\footnotetext{
${ }^{30}$ It refers to the Act on Court Fees and Tariff for Lawyers' Fees and Expenses.

${ }^{31}$ See footnote 22 .

${ }^{32}$ Lawyers' Tariff, item no. 17.

${ }^{33}$ A subjective right may also be successfully protected in a lawsuit with multiple plaintiffs or multiple defendants.
} 
becomes the reason for exercising the right to legal protection, and not its consequence, as it should be.

The right to compensation of litigation costs is abused by requiring payment of costs for taken actions although the costs were not actually incurred, by using the language formulations of the Lawyers' Tariff, which prescribes lawyer fees for drafting the complaint and other submissions. It is often disregarded that lawyer's fees are envisaged due to the fact that charging clients is their sole source of income; lawyers are independent professionals who provide legal assistance to citizens and earn their living by charging clients for the provided services by using their legal knowledge. Thus, the lawyer did use his legal knowledge and practical experience when he drafted the first complaint against the defendant and some other submission for his first client but, after that, he did not employ any additional knowledge when he copy-pasted the same complaint and submission and used it against the same defendant for the next and every subsequent client. As already noted, the oral activities performed at a hearing in mass tort lawsuits are identical. ${ }^{34}$

Prevention of these forms of abuse of rights primarily entails narrowing the opportunity for the abuse of rights; it further implies that abuse should be recognized and adequately sanctioned. In the next part of the paper, the author endeavours to respond to the following questions: can the existing legal solutions be used to adequately prevent and eliminate the abuse of rights, or is there a need for amending the legislation in this area?

\section{The EXISTING LegAL Mesures to PREVENT ABUSE}

The Constitution of the Republic of Serbia ${ }^{35}$ prescribes that everyone shall have the right to a public hearing before an independent and impartial tribunal established by the law. The European Convention for Protection of Human Rights and Fundamental Freedoms (ECHR) acknowledges the right to a fair trial; and the Serbian Civil Procedure Act (CPA) prescribes that parties have the right to a lawful, equal and fair protection (Art. 2 CPA). This Act specifically regulates that a court can only prevent and punish any abuse (Article 9. Para. $1 \mathrm{CPA}$ ). It follows from these provisions that a party cannot be denied the right to file a complaint; so, the court cannot reject a complaint if it determines that it constitutes the abuse of rights.

The court may punish a party or other participants who use their procedural authorities in contravention with the envisaged goals and objectives (Article 186 para. 2 CPA). Punishing the attorney for the abuse of right to file a lawsuit is rare in Serbian judicial practice, which does not mean that this measure should not be applied. One of the reasons why it is not applied is the possible extension of the length of proceedings, as there is a possibility to file an appeal against such a decision, but this could be avoided by passing a decision on punishment which is issued along with the final judgment. The fact is that the courts are overloaded with cases and do not have time to make penal decisions ${ }^{36}$. However,

\footnotetext{
${ }^{34}$ In mass tort litigation, there are no unexpected situations at hearings, such as: filing objections that had not been posed formerly; introducing new evidence that has not been formerly disclosed which would potentially call for a additional statement of the party's attorney. In mass tort litigation, the entire course of proceedings takes place according to a well-known scenario, both in terms of the parties' litigation actions and in terms of court actions.

${ }^{35}$ Article 32 of the Constitution of the Republic of Serbia, Official Gazette of RS, no. 98/2006.

${ }^{36}$ Such a decision has to be justified by relevant statistical data on the number of filed lawsuits by the same lawyer against the same defendant, the amount of procedure costs in all procedures, the amounts of claims, and
} 
such practice does not justify the non-application of the aforementioned legal provision since the task of the court is not only to "resolve cases" but also to prevent and punish the abuse of rights. In this way, the court protects the public interest, by making it clear to all participants in the proceedings that they have acted contrary to the envisaged goals of the civil procedure.

Joinder of cases is also one of the instruments that can successfully prevent the abuse of rights performed by filing multiple lawsuits against the same defendant (Art. 328 CPA) ${ }^{37}$. The insufficient use of this institute in mass tort lawsuits has been justified by administrative reasons: in the period when courts were literally "buried" under the heavy caseload of new lawsuits ${ }^{38}$ (due to the lack of time, space and personnel), it was impossible to choose which cases would be joined, which was particularly aggravated by the fact that all lawsuits were not filed by the same attorney at the same time. The cost-effectiveness of the procedure is the key factor for not joining the cases, which are at different stages of civil procedure; the situation was further complicated by allowing the parties to submit an expert witness report before the first hearing (Articles 261 and 263 CPA), but this authority was not used in all litigations.

Abuse of rights can be punished by not recognizing the costs for drafting a complaint and other submissions in mass tort litigation to the party which was successful in litigation; such a measure can be used to prevent future abuses. As already explained, in "mass lawsuits", complaints and other submissions are not drawn in all cases where several persons are represented by one lawyer because they are almost identical in terms of content as well as in respect of verbal actions taken at the hearing. In the legal reasoning pertaining to such a decision, the court may apply the principle of liability (fault) $)^{39}$, and explain that the lawyer himself has incurred these costs by filing several lawsuits against the same defendant, acting on behalf of several plaintiffs, thereby causing costs that would not have incurred if he had filed one lawsuit. The filing of an individual lawsuit significantly increases the costs and expenses of civil litigation, which is precisely the circumstance constitutes the abuse of rights.

\section{FINAL CONSIDERATIONS}

The increasing number of mass tort lawsuits with small value claims and large amounts of litigation procedure costs shows that courts rarely apply the principle of prohibition of abuse of rights by approving the high amounts for civil procedure costs compensation, nor do they use other mechanisms to prevent the abuse and punish the offenders. There are only occasional cases where the court applied these principles and

\footnotetext{
the explanation of the court conclusion that procedural competences have been abused of rights by filing a greater number of lawsuits instead of one.

${ }^{37}$ Article 328 of CPA: If before the same court there are multiple procedures between same parties or several procedures where the same person is opposed to various plaintiffs or defendants, all these procedures may be joined by a court decision in order to be argued together, so as to expedite deliberation and reduce costs. The court may make a joint judgment for all the procedures which have been joined.

${ }^{38}$ This relates to mass tort lawsuits against the National Employment Service, Preschool Institution Pčelica Niš and similar. In this period, at the Basic Court in Niš, at certain times there were not enough case folders to form a case, judges would receive several dozens of cases on a daily basis, clerks could not perform timely delivery of lawsuits and subpoenas, so there were delays for several weeks.

${ }^{39}$ See footnote 31
} 
decided otherwise ${ }^{40}$. As it is not realistic to expect substantial changes in judicial practice, it it necessary to institute relevant changes of laws and other regulations on the compensation of costs in civil procedure.

In pursuit of appropriate legal solutions, it is necessary to bear in mind that lawsuits conducted under the rules of general civil procedure are not an efficient means of resolving mass disputes. This paper explains how this method is misused in order to charge the highest possible civil procedure costs. It is, therefore, necessary to introduce some of the institutes existing in comparative legislation, not only in order to reduce the litigation costs and expenses but also to ensure uniformity of the judicial practice and reduce the caseload that burdens the courts.

It is therefore necessary introduce

It is also necessary to introduce appropriate amendments to the Civil Procedure Act in the part that authorizes the court, when deciding on the request for compensation of the procedure costs, to recognize only the costs that were actually incurred by the party until the date of filing the request. The rule that would oblige the party to prove that it really paid the costs it is claiming would contribute to preventing abuse. The abuse of rights by a lawyer would not be an issue if the party really wants and insists that its small value claim is protected in an expensive civil procedure, and if the party is ready to allocate significant funds for the exercise of this right and indeed advances the funds (pay court fees; pay the amount for an expert witness fee into the judicial deposit, which should replace the frequently used expert statement on the record that the reward has been paid; provide proof that he has paid the attorney for representation).

Changes in the Lawyer's Tariff would also contribute to the prevention of the abuse of rights, provided that the Tariff would prescribe special fees for actions taken in mass tort lawsuits, in significantly lower amounts than the existing ones. Due to the common practice of copying complaints and other submissions, and the same manner of representation at hearings, it is obvious that in mass tort lawsuits lawyers do not exert their best effort, use their legal knowledge and spend the same time on these cases as compared to lawsuits with different content. It is therefore unjustifiable to identify representation in mass tort litigation with legal representation in lawsuits aimed at protecting individual subjective rights.

\section{REFERENCES}

Betetto, N. (2011), Vzorčni postopek (Litigation Procedure), Pravni letopis, pp. 231-241

Bodiroga, N. (2012), Neki problemi u primeni Zakona o parničnom postupku u sporovima male vrednosti (Some issues in the application of Civil Procedure Act in small value disputes) Zbornik radova Pravnog fakulteta u Novom Sadu, 2015, br. 2, pp. 653-670

Grbin, I. (1990), Troškovi parničnog postupka (Litigation Costs), Građansko parnično pravo u praksi, p. 86

Janićijević, D. (2006), Rešavanje tzv. klasnih sporova u parničnom i arbitražnom postupku (Resolving Class Action Disputes in Litigation and Arbitration Proceedings), Zbornik radova Pravnog fakulteta u Nišu, br. 47, pp. 109-122

Kovačević-Kuštrimović, R. (1996), Domen primene načela zabrane zloupotrebe prava (Domain of applying the principle of prohibition of abuse of rights), Zloupotreba prava, Niš, str. 17-30

\footnotetext{
${ }^{40}$ In the judgment of the Basic Court in Niš P5116/16 from 04/04/2017, the Court adopting the claim of the plaintiff M. K. towards the City of Niš and preschool institution"Pčelica" Niš for payment of the amount of 590.00 RSD in the name of damage compensation, and completely rejected the the request to grant the payment of procedure costs, ruling that such a claim consitutes the abuse of rights.
} 
Marković, M. (1982), Građansko procesno pravo. Knj. 1, Parnični postupak. Sv. 2., Parnične radnje (Civil Procedure Book 1, Litigation Proceedings vol. 1, Litigation Actions), Niš, Pravni fakultet, Skriptarnica PK SSO

Marković, M. (1996), Teorija zloupotrebe prava u uporednom pravu-doktorska disertacija (Theory on the Abuse of Rights in Comparative Law, doctoral dissertation/translated from French) prevod sa francuskog prof. dr Boža Marović i prof Vladimir Marković, Beograd-Niš.

Petrušić, N. \& Simonović, D. (2012), Komentar Zakona o parničnom postupku (Commentary on the Civil Procedure Act), Beograd, Službeni glasnik

Petrušić, N. (2014), Kolektivna pravna zaštita: Evropski pristup (Collective Redress: the European approach), Zbornik radova Pravnog fakulteta u Nišu, br. 68, str. 303-324

Popović, M. (1996), Borba za pravo, zloupotreba prava i odgovornosti kao moralni pojmovi (Fighting for Law, Abuse of Rights and Liability as moral concepts), Zloupotreba prava, Niš, p. 3 -10;

Poznić, B. \& Rakić-Vodinelić, V. (2010), Građansko procesno pravo (Civil Procedure Law), Beograd, Savremena administracija, p. 433

Sherman, E. (2002), Group Litigation under Foreign Legal Systems: Variation and Alternatives to American Class Action, De Paul Law Review, 2002, no.52, 2002.

Stanković, G. (1998), Građansko procesno pravo (Civil Procedure Law), Niš, Pravni fakultet-Niš, p. 285

Stojanović, D. (1970), Zloupotreba prava u našoj teoriji, zakonodavstvu i sudskoj praksi (Abuse of Rights in Serbian theory, legislation and judicial practice), Zbornik Pravnog fakulteta u Niš, 1970, br.7, p. 92

Triva, S. \& Dika M. (2004), Građansko procesno pravo (Civil Procedure Law), Zagreb, Narodne novine, p. 462

Vodinelić, V. V. (1997), Takozvana zloupotreba prava (The so-called Abuse of Rights), Beograd.

Vukadinović, G. (1996), Temelji teorije zloupotrebe prava (Foundations of the Abuse of Rights Theory), Zloupotreba prava, Niš, 1996, pp. 11-16

Zarić, S. (2005), Posebna pravila postupka u sporovima male vrednosti (Special Rules of Procedure in Small Value Claims), Bilten Vrhovnog suda Srbije, Beograd, 2005, br. 2, pp. 253-278

Zoroska-Kamilovska T. \& Shterjova T. (2014), Postupci za zaštitu kolektivnih prava i interesa sa osvrtom na stanje u Republici Makedoniji (Proceedings for Protection of Collective Rights and Interests, with reference to the situation in the FRY Macedonia), Pravo-teorija i praksa, 2014, br.7-9, pp. 49

Pravni portal: Trajanje sporova male vrednosti (Statute of Limitations in Small Value Claims), Profi Sistem, 1. avgust 2016, dostupno na http://www.pravniportal.com/trajanje-sporova-male-vrednosti/ (pristup 12.10.2017).

Radio Televizija Srbije-RTS: Nacionalna služba za zapošljavanje gubi sporove sa građanima (Radio Television Serbia-RTS: National Employment Service loses disputes with citizens), 28 septembar 2016; dostupno na http://www.rts.rs/page/stories/sr/story/125/drustvo/2469793/nacionalna-sluzba-za-zaposljavanje-gubisporove-sa-gradjanima.html (pristup 12.10.2017).

\section{Legal acts}

Federal Rules of Civil Procedure, United States of America; available at www.federalrulesofcivilprocedure.org (accessed 12/10/2017)

Commission recommendation of 11 June 2013 on common principles for injunctive and compensatory collective redress mechanisms in the Member States concerning violations of rights granted under Union Law (2013/396/EU), Official Journal L 201/60, 26/7/2013; avialiable at https://eur-lex.europa.eu/legalcontent/EN/TXT/HTML/?uri=CELEX:32013H0396\&from=EN (12/10/2017)

Устав Републике Србије (Constitution of the Republic of Serbia) Сл. Гласник РС, бр. 98/2006)

Закон о адвокатури (Advocacy Act), Сл. Гласник РC, бр. 31/2011 и 24/2012-одлука УС).

Закон о парничном поступку (Civil Procedure Act), Службени гласник РС, бр. 72/2011, 49/2013-одлука Уставог суда, 74/2013-одлука Уставног суда, 55/2014.

Закон о парничном поступку (Civil Procedure Act), Службени гласник PC, бр. 72/2011,

Zakon o pravdnem postopku (Civil Procedure Act), Uredni list Republike Slovenije, št.26/1999-45/20008).

Закон о судским таксама (Act on Court Fees), Службени гласник РC, бр. 28/94, 53/97, 16/97, 34/01-други закон, 9/02, 29/04, 116/08-други закон, 31/09, 101/11, 93/14 и 106/15

Правилником о накнади трошкова у судским поступцима (Rulebook on Cost Compensation in Court Proceedings).Службени гласник PC, бр. 6/16 и 62/16, (herein: Rulebook ).

Наредба о накнадама трошкова за исплату паушала судија и запосленима у Основном суду у Нишу и накнадама за употребу службеног возила (Order on cost compensation for payment of flat-rate fees to judges and employees of the Basic Court in Niš and fees for use of vehicles), Cy I-1 6/16 од 18.04.2016.

Тарифа о наградама и накнадама трошкова за рад адвоката (Tariff on Lawyers's Fees and Expenses), Службени гласник РС, бр. 121/12, у даљем тексту: Адвокатска тарифа 
Case Law

Одлука Уставног суда (Judgment of the Constitutional Court) ИУЗ 51/2012 од 23.05.2013. објављена у Службеном гласнику РС, бр. 49/2013.

Пресуда Основног суда у Нишу (Judgment of the Basic Court in Nis) П5116/16 од 04.04.2017

Пресуда Основног суда у Нишу (Judgment of the Basic Court in Nis) П 6750/15 од 12.09.2017.

Пресуда Основног суда у Нишу (Judgment of the Basic Court in Nis) П 2706/14 од 05.03.2015.

Пресуда Основног суда у Нишу (Judgment of the Basic Court in Nis) П 14313/15 од 13.09.2016.

\section{NAKNADA TROŠKOVA PARNIČNOG POSTUPKA U MASOVNIM PARNICAMA}

U ovom radu razmotrene su pravne posledice masovnih parnica u kojima je visina novčanog potraživanja višestruko niža od troškova parničnog postupaka. Ovu pojavu autorka razmatra s aspekta zabrane zloupotrebe prava, u kontekstu aktuelne sudske prakse, $i$ nudi predloge za unapređenje zakonske regulative kako bi se delotvorno predupredila zloupotreba prava.

Ključne reči: masovne parnice, troškovi postupka, zloupotreba prava.

Proofreading and copy-editing:

Gordana Ignjatović 